\title{
Descriptions of two new freshwater Neotropical species of Rhinebothrium (Cestoda: Rhinebothriidea) from Potamotrygon motoro (Chondrichthyes: Potamotrygonidae)
}

\author{
Adriana Menoret ${ }^{1,2}$ and Verónica A. Ivanov ${ }^{1,2}$ \\ ${ }^{1}$ Laboratorio de Helmintología, Departamento de Biodiversidad y Biología Experimental, Facultad de Ciencias Exactas \\ y Naturales, Universidad de Buenos Aires, Ciudad Universitaria, Pabellón II, piso 4, C1428EHA, Buenos Aires, Argentina; \\ ${ }^{2}$ Consejo Nacional de Investigaciones Científicas y Técnicas (CONICET), Argentina
}

\begin{abstract}
Two new species of Rhinebothrium (Cestoda, Rhinebothriidea) from potamotrygonid stingrays in the Neotropical region are herein described, which raises the total number of Rhinebothrium species known from Neotropical freshwaters to five. Rhinebothrium corbatai sp. n., and Rhinebothrium mistyae sp. n. were both collected from Potamotrygon motoro (Müller et Henle), captured in four tributaries of the Paraná River in Santa Fé Province, Argentina. The new species can be distinguished from their congeners, and from each other, by a combination of various features, including worm size (length and number of proglottids), number of loculi per bothridium, microthrix pattern, size of the cirrus sac, and the extent of the vas deferens. The discovery of these new species from P. motoro supports the pattern of high host specificity in this cestode genus, and reinforces the notion that some of the previous records of the enigmatic $R$. paratrygoni may correspond to new species of Rhinebothrium yet to be described.
\end{abstract}

Keywords: Rhinebothrium corbatai, Rhinebothrium mistyae, Santa Fé, Paraná River basin, Argentina

Rhinebothriidean cestodes in the genus Rhinebothrium Linton, 1890 are cosmopolitan parasites that inhabit both, marine and freshwater environments (Healy 2006, Healy et al. 2009). Among the 41 valid species of Rhinebothrium only 6 have been reported from freshwater hosts, 3 of which (Rhinebothrium paratrygoni Rego et Dias, 1976, Rhinebothrium copianullum Reyda, 2008, and Rhinebothrium paranaense Menoret et Ivanov, 2009) are endemic to the Neotropical region, as are their hosts, the potamotrygonid stingrays (Healy 2006, Reyda 2008, Menoret and Ivanov 2009).

Some freshwater Neotropical species of Rhinebothri$u m$ seem to be highly host specific, such as $R$. paranaense and $R$. copianullum, which are restricted to a single host species and a single river basin (Reyda 2008, Menoret and Ivanov 2009). In contrast, published records of $R$. paratrygoni suggest that it is a generalist species, having been reported from 9 host species in several different river basins of South America (Rego and Dias 1976, Brooks et al. 1981, Brooks and Amato 1992, Marques 2000). These records of $R$. paratrygoni have been considered dubious by Reyda (2008) and Menoret and Ivanov (2009), since the identity of those specimens remains to be confirmed. Recent collections of cestodes from stingrays in the Lower Paraná River, led to the discovery of two new species of
Rhinebothrium, described herein, from the South American freshwater stingray Potamotrygon motoro (Müller et Henle).

\section{MATERIALS AND METHODS}

A total of 37 specimens of Potamotrygon motoro were caught in 1999-2005 in the Paraná River basin in rivers Colastiné $\left(31^{\circ} 40^{\prime} \mathrm{S}, 60^{\circ} 46^{\prime} \mathrm{W}\right)$, Coronda $\left(31^{\circ} 50^{\prime} \mathrm{S}, 60^{\circ} 49^{\prime} \mathrm{W}\right)$, Alto Verde $\left(31^{\circ} 39^{\prime} \mathrm{S}, 60^{\circ} 40^{\prime} \mathrm{W}\right)$, and Setúbal Lagoon $\left(31^{\circ} 32^{\prime} \mathrm{S}, 60^{\circ} 36^{\prime} \mathrm{W}\right)$ in Santa Fé Province, Argentina. Cestodes of the genus Rhinebothrium were recovered from the spiral intestine of 14 stingrays.

The worms were fixed in $10 \%$ formalin and transferred to $70 \%$ ethanol. Specimens and detached gravid proglottids prepared for light microscopy were hydrated in a graded ethanol series, stained with Harris' haematoxylin, dehydrated in a graded ethanol series, cleared in methyl salicylate, and mounted in Canada balsam. Specimens prepared for scanning electron microscopy (SEM) were hydrated in a graded ethanol series, postfixed in $1 \%$ osmium tetroxide overnight at room temperature, dehydrated in a graded ethanol series, and dried using hexamethyldisilazane. Specimens were mounted on stubs with carbon tape, coated with $\sim 40 \mathrm{~nm}$ of gold/palladium in a Thermo VG Scientific Polaron SC 7630 and examined with a Philips XL 30 scanning electron microscope. Terminology for the morphology of microtriches follows Chervy (2009).

Mature proglottids were embedded in paraffin and serial cross-sections were cut at a thickness of $8 \mu \mathrm{m}$. Sections were

Address for correspondence: V.A. Ivanov, Laboratorio de Helmintología, Departamento de Biodiversidad y Biología Experimental, Facultad de Ciencias Exactas y Naturales, Universidad de Buenos Aires, Ciudad Universitaria, Pabellón II, piso 4, Lab. 52, C1428EHA, Buenos Aires, Argentina. Phone: +54 1145763300 ext. 332; Fax: +54 114576 3384; E-mail: ivanov@bg.fcen.uba.ar 
stained with Harris' haematoxylin, counterstained with eosin, and mounted in Canada balsam. In several specimens one bothridium was removed from the scolex and temporarily mounted in glycerine to clearly observe the arrangement of septa and loculi on the distal bothridial surface. Sections, whole mounts and temporary mounts were observed and measured with a Zeiss Axioskop microscope. Drawings were made with the aid of a drawing tube. Measurements include the range, followed in parentheses by the mean, standard deviation, number of worms examined (n), and the total number of observations when more than one measurement per worm was taken $(n)$. All measurements are in micrometres unless otherwise stated.

Type specimens are deposited at the Colección Parasitológica, Museo Argentino de Ciencias Naturales, Buenos Aires, Argentina (MACN-Pa), and at the Institute of Parasitology, Academy of Sciences of the Czech Republic, České Budějovice, Czech Republic (IPCAS). Additional information and images of each host specimen can be obtained by entering the host specimen number (SF004, SF010, SF011, SF021, SF022, SF029, SF030, SF031, SF032, SF033, SF035, SF036; SF058, SF071) in the host specimen database at https://web2.uconn.edu/tapeworm/ hosts.php.

\section{RESULTS}

\section{Rhinebothrium corbatai sp. n.}

Figs. 1-3, 7-13, 22-25

Description (based on 9 complete mature specimens and 1 strobila without scolex, cross-sections of 2 strobilae with mature proglottids, and 2 specimens prepared for SEM): Worms euapolytic, 3.3-7.5 $(5.1 \pm 1.4, \mathrm{n}=9) \mathrm{mm}$ long; greatest width at level of scolex 0.6-1.0 (0.7 \pm 0.1 , $\mathrm{n}=10) \mathrm{mm}$; proglottids craspedote, 96-190 (128 \pm 31 , $\mathrm{n}=9)$ per worm, 93-187 $(130 \pm 32, \mathrm{n}=9)$ immature proglottids, $2-4(3.5 \pm 0.5, \mathrm{n}=10)$ mature proglottids (Fig. 1). No attached gravid proglottids were seen.

Scolex 410-760 $(630 \pm 100, n=9)$ long composed of 4 stalked, facially loculate bothridia and cephalic peduncle; apical organ absent (Fig. 2). Scolex proper 300-600 $(500 \pm 100, \mathrm{n}=10)$ long. Bothridia 450-750 (659 \pm 113 , $\mathrm{n}=7, n=8)$ long, 200-350 (268 $\pm 5, \mathrm{n}=10, n=11)$ wide. Distal bothridial surface divided by median longitudinal septum and 35-37 $(36.5 \pm 0.5, \mathrm{n}=5)$ transverse septa delimiting 2 columns of 35-37 $(36.0 \pm 0.5, \mathrm{n}=5)$ loculi per column and anterior single loculus, resulting a total of $71-75(73 \pm 1, n=5)$ loculi per bothridium. Longitudinal septum extending from posterior margin of anteriormost loculus to posterior margin of bothridium. Anteriormost loculus single, 22-27 (24 $\pm 2, \mathrm{n}=3)$ long, 17-22 $(19 \pm 2, \mathrm{n}=3)$ wide. Posteriormost loculi 25-27 $(26 \pm 1, \mathrm{n}=3, n=6)$ long, 10-13 (12 $\pm 1, \mathrm{n}=3, n=6)$ wide (Figs. 2, 3, 7). Proximal bothridial surface covered by gladiate spinitriches $0.93-1.19$ long, $0.30-0.35$ wide at base, $7-8$ spinitriches $/ \mu \mathrm{m}^{2}$, interspersed with acicular filitriches (Fig. 8). Distal bothridial surface covered by coniform spinitriches, $0.90-1.07$ long, $0.25-0.30$ wide at base, $8-12$ spinitriches $/ \mu \mathrm{m}^{2}$, interspersed with papilliform filitriches, $0.15-0.20$ long, approximately 7-9 filitriches/ $\mu \mathrm{m}^{2}$ (Figs. 11, 12). Bothridial stalks 200-335 (239 \pm 37 , $\mathrm{n}=9, n=19$ ) long, attached to middle of proximal bothridial surface; covered with acicular filitriches, 0.30-0.35 long, 0.12-0.13 wide at base, approximately 28-31 filitriches $/ \mu \mathrm{m}^{2}$ (Fig. 10). Cephalic peduncle 107-160 $(127 \pm 18, \mathrm{n}=9)$ long, 85-130 $(109 \pm 15, \mathrm{n}=9)$ wide, covered by acicular filitriches, $0.18-0.21$ long, $0.09-0.11$ wide at base, $33-39$ filitriches $/ \mu \mathrm{m}^{2}$.

Immature proglottids wider than long (Figs. 1, 13). Mature proglottids (excluding terminal proglottid) wider than long to longer than wide, $120-235(177 \pm 32, \mathrm{n}=9$, $n=22)$ long, 100-240 (152 $\pm 36, \mathrm{n}=9, n=22)$ wide (velum not included in proglottid length); length to width ratio $0.5-1.9(1.2 \pm 0.3, \mathrm{n}=9, n=44): 1$; velum 5-12 $(8 \pm 3$, $\mathrm{n}=9, n=18)$ long, covering $1.4-14.9 \%(4.4 \pm 3.4, \mathrm{n}=9$, $n=19)$ of adjacent proglottid. Marginal genital pores alternate irregularly, $45-79 \%(66 \pm 9, \mathrm{n}=9, n=19)$ from posterior margin of proglottid.

Terminal proglottids mature, longer than wide, 235-370 (299 $\pm 51, \mathrm{n}=9)$ long, 90-180 (132 $\pm 30, \mathrm{n}=9)$ wide; length to width ratio $1.5-3.3(2.3 \pm 0.5, \mathrm{n}=10$, $n=11$ ): 1 (Figs. 1, 22). Terminal proglottid covered by acicular filitriches, $0.15-0.20$ long, $0.08-0.12$ wide at base, $41-44$ filitriches $/ \mu \mathrm{m}^{2}$ (Fig. 9).

Testes oval, 3-5 (4 $\pm 1, \mathrm{n}=9, n=28)$ per proglottid, 20-57 (39 $\pm 10, \mathrm{n}=9, n=55)$ long, $15-47(28 \pm 8, \mathrm{n}=9$, $n=55)$ wide, extending from near anterior margin of proglottid to anterior margin of cirrus sac, 1 row deep in cross-section (Figs. 22, 23). Cirrus sac pyriform, curved posteriorly, 50-87 (65 $\pm 10, \mathrm{n}=9, n=19)$ long, 28-57 (41 $\pm 8, \mathrm{n}=9, n=19$ ) wide, containing cirrus covered by spinitriches 3 long (Figs. 22, 24). Vas deferens extending anteriorly from level of Mehlis' gland to level of posteriormost testes on dorsal side of proglottid, entering cirrus sac anteriorly, maximum width $10-12(12 \pm 1, \mathrm{n}=1$, $n=3$ ).

Vagina thick-walled, opening anterior to cirrus sac in genital atrium, running along anterior margin of cirrus sac, descending posteriorly to ootype region. Ovary lobulated, $\mathrm{H}$-shaped in dorsoventral view (Fig. 22), tetra-lobed in cross-section at level of ovarian isthmus (Fig. 25), maximum width 62-127 $(90 \pm 23, \mathrm{n}=8, n=18)$, poral lobe $37-65(52 \pm 10, \mathrm{n}=7, n=18)$, aporal lobe slightly longer than poral lobe, $42-75(58 \pm 9, \mathrm{n}=7, n=18)$ long. Vitelline follicles oval, $7-15(11 \pm 3, \mathrm{n}=6, n=18)$ long, $5-12$ $(8 \pm 3, n=6, n=18)$ wide, distributed in columns of 2 follicles deep (1 dorsal, 1 ventral) on each side of proglottid, interrupted dorsally on poral side at level of terminal genitalia, not interrupted by the ovary (Fig. 22). Mehlis' gland $20-30(27 \pm 3, \mathrm{n}=3, n=11)$ in diameter, posterior to ovarian isthmus. Uterus saccate, visible in mature proglottids; extending to near posterior margin of proglottid and anteriorly to near anterior margin of proglottid. 


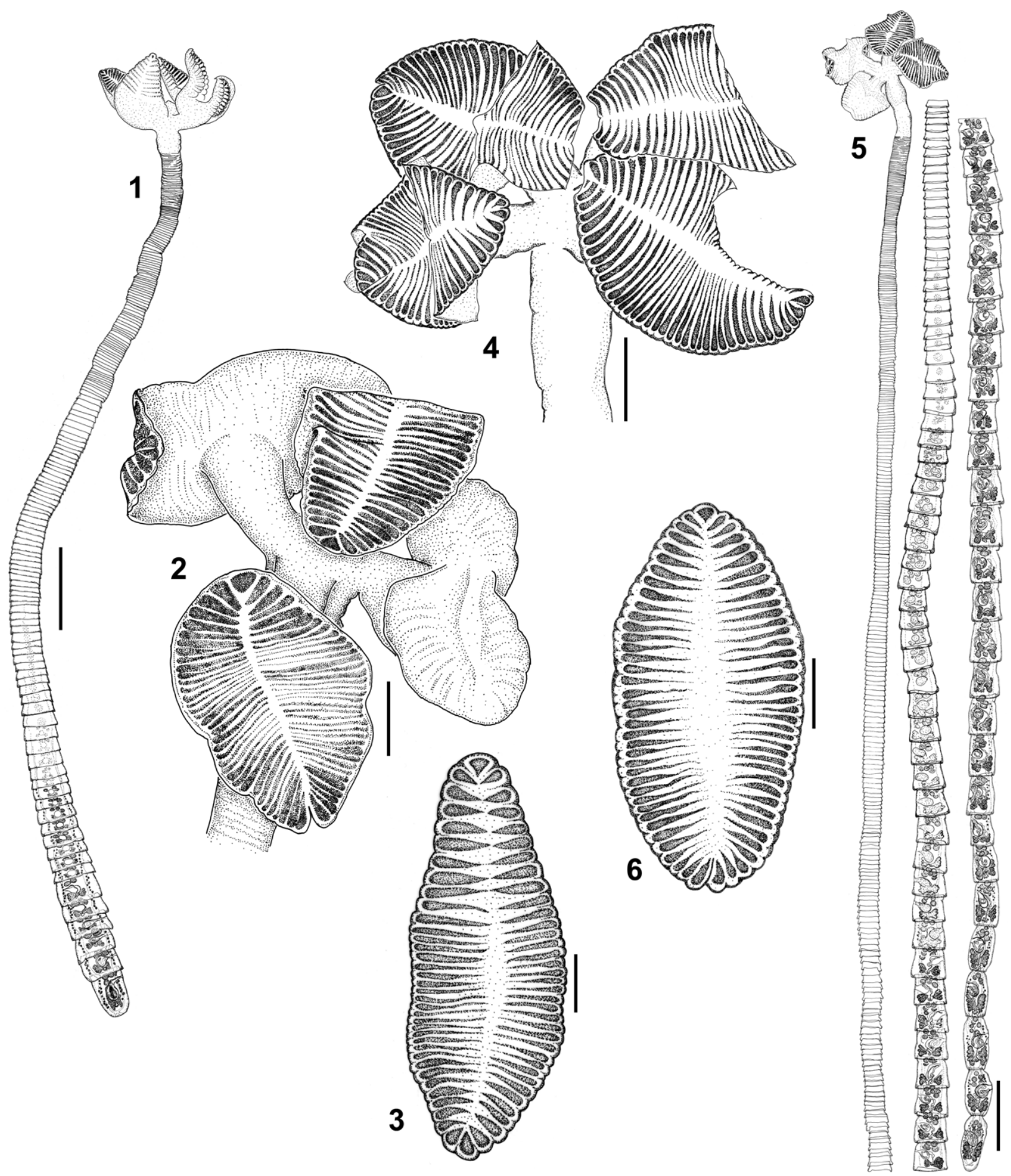

Figs. 1-3. Rhinebothrium corbatai sp. n. Fig. 1. Entire worm (holotype MACN-Pa 515). Fig. 2. Scolex (paratype MACN-Pa 515). Fig. 3. Bothridia, distal surface (paratype MACN-Pa 515). Figs. 4-6. Rhinebothrium mistyae sp. n. Fig. 4. Entire worm (holotype MACN-Pa 516). Fig. 5. Scolex (paratype MACN-Pa 516). Fig. 6. Bothridia, distal surface (paratype MACN-Pa 516). Scale bars: Fig. $1=500 \mu \mathrm{m}$; Figs. $2,3=100 \mu \mathrm{m}$; Fig. $4=250 \mu \mathrm{m}$; Fig. $5=1 \mathrm{~mm}$; Fig. $6=150 \mu \mathrm{m}$. 

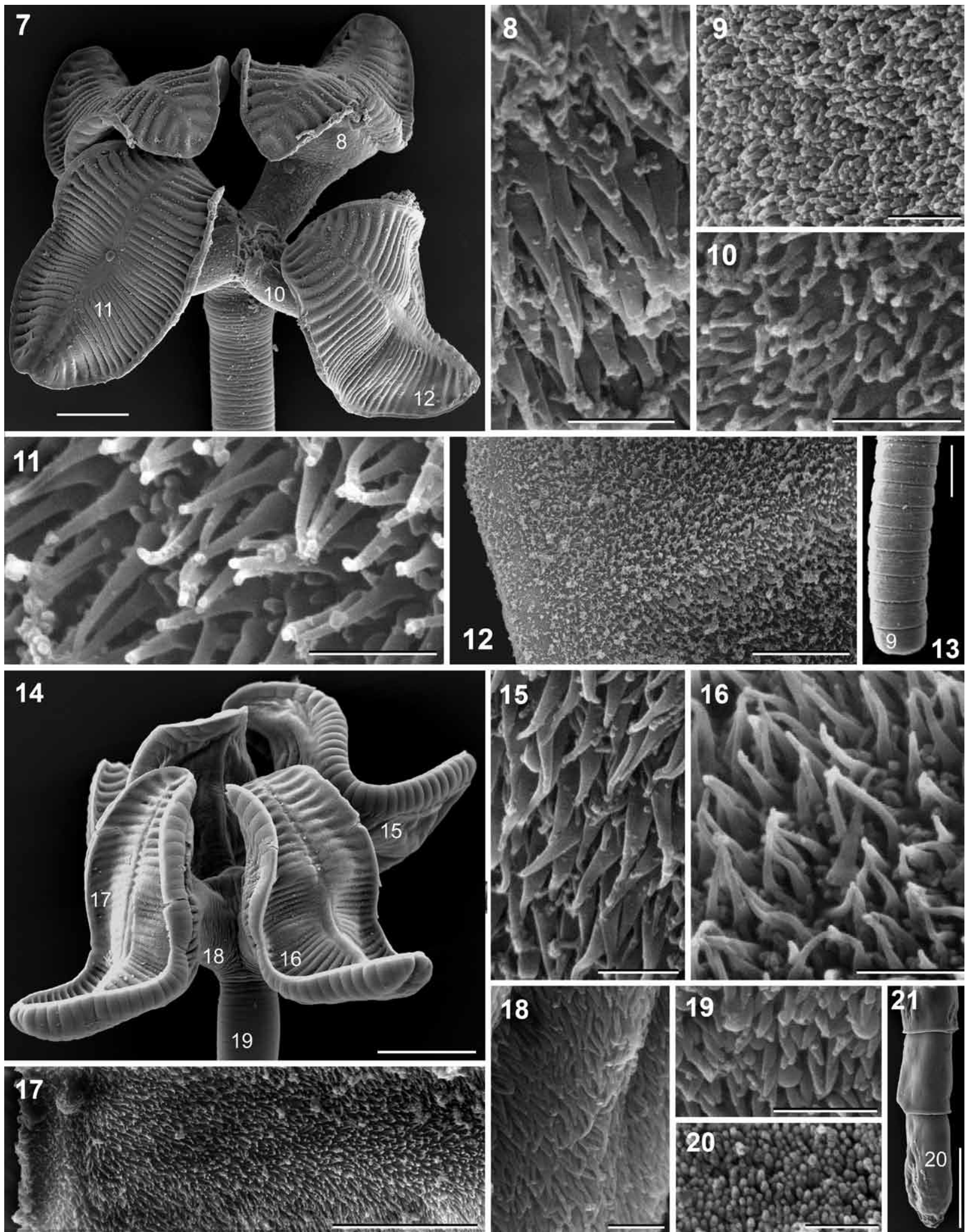

Figs. 7-13. Rhinebothrium corbatai sp. n., scanning electron micrographs. Numbers on scolex micrographs indicate locations and figure numbers of surface images. Fig. 7. Scolex. Fig. 8. Proximal bothridial surface. Fig. 9. Surface of mature proglottid. Fig. 10. Stalk surface. Fig. 11. Distal bothridial surface. Fig. 12. General view of distal bothridial surface of loculus and transverse septa. Fig. 13. Posteriormost proglottids. Figs. 14-21. Rhinebothrium mistyae sp. n., scanning electron micrographs. Fig. 14. General view of scolex. Fig. 15. Proximal bothridial surface. Fig. 16. Distal bothridial surface. Fig. 17. General view of distal bothridial surface of loculi and transverse septa. Fig. 18. Surface of bothridial stalk. Fig. 19. Surface of cephalic peduncle. Fig. 20. Surface of mature proglottid. Fig. 21. General view of mature proglottids. Scale bars: Fig. $7=100 \mu \mathrm{m}$; Figs. 8-11, 15, 16, 18, 19=1 $\mu$ m; Figs. $12,17=10 \mu \mathrm{m}$; Figs. 13, $21=500 \mu \mathrm{m}$; Fig. $14=250 \mu \mathrm{m}$; Fig. $20=2 \mu \mathrm{m}$. 


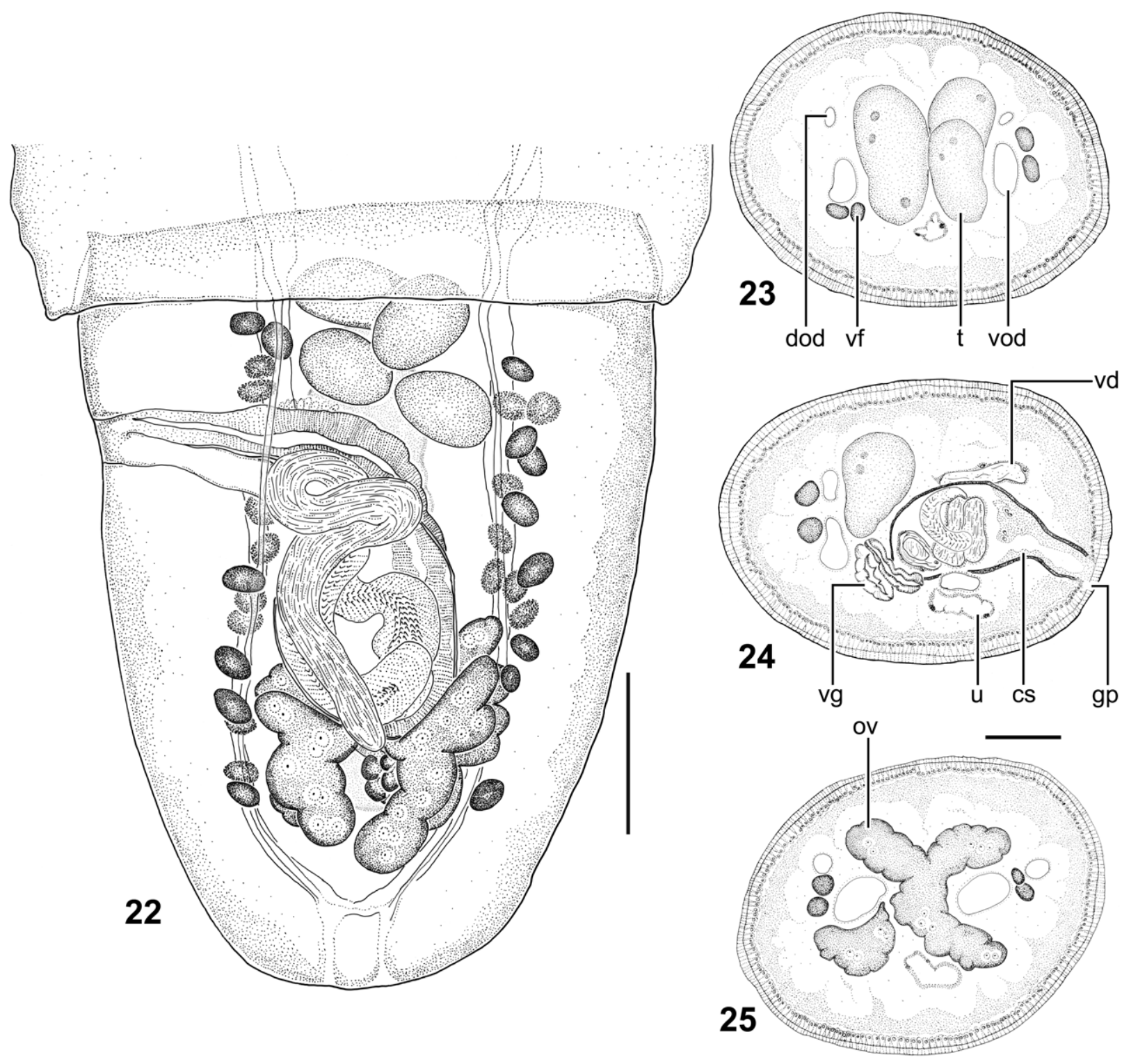

Figs. 22-25. Rhinebothrium corbatai sp. n. Fig. 22. Dorsal view of terminal proglottid (paratype MACN-Pa 515). Figs. 23-25. Crosssections of mature proglottid (paratype MACN-Pa 515). Fig. 23. At the level of testes. Fig. 24. At the level of cirrus sac. Fig. 25. At the level of ovarian isthmus. Abbreviations: cs - cirrus sac; dod - dorsal osmoregulatory duct; gp - genital pore; ov - ovary; $\mathrm{t}$ - testis; $\mathrm{u}$ - uterus; $\mathrm{vd}$ - vas deferens; vf - vitteline follicle; vg - vagina; vod - ventral osmoregulatory duct. Scale bars: Fig. $22=50 \mu \mathrm{m}$; Figs. $23-25=25 \mu \mathrm{m}$.

Type host: Potamotrygon motoro (Müller et Henle), South American freshwater stingray (Rajiformes, Potamotrygonidae).

Ty p e loc a lity: Colastiné River, Paraná River basin, Santa Fé, Argentina $\left(31^{\circ} 40^{\prime} \mathrm{S}, 60^{\circ} 46^{\prime} \mathrm{W}\right)$.

O the r l o c a lity: Coronda River, Paraná River basin, Santa Fé, Argentina $\left(31^{\circ} 50^{\prime} \mathrm{S}, 60^{\circ} 49^{\prime} \mathrm{W}\right)$.

Site of infection: Spiral intestine.

Prevalence and intensity of infection: Eight of 37 hosts examined (22\%); 1-5 (2) worms per host.

Specimens deposited: Holotype and 3 paratypes, MACN-Pa No. 515/1-4 (whole worms); 2 paratypes, IPCAS
No. C-605. Additional specimens (whole mounts, histological sections, and specimens prepared for SEM) retained in the personal collection of Verónica Ivanov.

Etymology: This species is named after "Corbata", the Welsh terrier dog of the first author.

Remarks. Among the 41 valid species of Rhinebothrium, $R$. corbatai most closely resembles 13 species in the genus in possessing more than 95 proglottids per worm (Healy 2006, Reyda 2008, Menoret and Ivanov 2009). The new species can be distinguished from these as follows: $R$. corbatai is markedly smaller than $R$. ceylonicum Ship- 
ley et Hornell, 1906, R. chilensis Euzet et Carvajal, 1973, $R$. ditesticulum Appy et Dailey, 1977, R. leiblei Euzet et Carvajal, 1973, R. maccallumi Linton, 1924, R. monodi Euzet, 1954, R. tetralobatum Brooks, 1977, R. tumidulum (Rudolphi, 1819), and $R$. verticillatum (Subhapradha, 1955) (3.3-7.5 mm long vs. more than $9.6 \mathrm{~mm}$ long). Whereas $R$. hui (Tseng, 1933), R. margaritense Mayes et Brooks, 1981, and $R$. walga (Shipley et Hornell, 1906) have less than 44 loculi per bothridium, $R$. corbatai has 71-75 loculi. This feature also facilitates the differentiation between $R$. corbatai and $R$. euzeti Williams, 1958, which has more than 78 loculi per bothridium.

Whereas each of the other three valid freshwater Neotropical species of Rhinebothrium are greater than $23 \mathrm{~mm}$ in total length, $R$. corbatai only reaches $7.5 \mathrm{~mm}$ in length and it also has fewer proglottids per worm (96-190 vs. more than 456) compared to these other species. In addition, $R$. corbatai differs from $R$. copianullum and $R$. paranaensis in the number of mature proglottids per worm (2-4 vs. more than 23 ), and in the number of loculi per bothridium ( $71-75$ vs. $78-87$ and 65-69, respectively).

\section{Rhinebothrium mistyae sp. n.}

Figs. 4-6, 14-21, 26-29

Description (based on 15 complete mature specimens, 1 strobila without scolex, cross-sections of 1 strobila with mature proglottids, and 2 mature specimens prepared for SEM): Worms euapolytic, 20.0-59.9 (37.0 \pm 10.6 , $\mathrm{n}=15) \mathrm{mm}$ long; greatest width at level of scolex $0.8-1.3$ $(1.0 \pm 0.1, \mathrm{n}=15) \mathrm{mm}$; proglottids craspedote, 353-974 $(554 \pm 165, \mathrm{n}=15)$ per worm, 297-925 (528 \pm 170 , $\mathrm{n}=15)$ immature proglottids, $10-49(26 \pm 14, \mathrm{n}=15)$ mature proglottids (Fig. 5).

Scolex 910-1,410 $(1,110 \pm 200, \mathrm{n}=11)$ long, composed of 4 stalked, facially loculate bothridia and cephalic peduncle; apical organ absent (Figs. 4, 14). Scolex proper $800-1,300(1,000 \pm 100, \mathrm{n}=15)$ long. Bothridia $580-1,050(785 \pm 172, \mathrm{n}=11, n=12)$ long, 330-680 $(460 \pm 81, \mathrm{n}=15, n=24)$ wide. Distal bothridial surface divided by median longitudinal septum and 37-39 $(38 \pm 1, \mathrm{n}=7, n=9)$ transverse septa, delimiting 2 columns of 37-39 (38 $\pm 1, \mathrm{n}=7, n=9)$ loculi per column and anterior single loculus, resulting in a total of 75-79 ( $77 \pm 2, \mathrm{n}=7, n=9$ ) loculi per bothridium. Longitudinal septum extending from posterior margin of anteriormost loculus to posterior margin of bothridium. Anteriormost loculus single, $25-30(28 \pm 2, \mathrm{n}=5)$ long, $15-43$ (33 \pm 10 , $\mathrm{n}=5)$ wide; posteriormost loculi, 22-32 (27 $\pm 3, \mathrm{n}=4$, $n=6)$ long, $12-14(14 \pm 1, \mathrm{n}=3, n=4)$ wide (Figs. 6, 14). Proximal bothridial surface covered by long gladiate spinitriches (Fig. 15), 1.06-1.34 long, 0.27-0.35 wide at base, $4-5$ spinitriches $/ \mu \mathrm{m}^{2}$, interspersed with acicular filitriches, $0.18-0.20$ long, $0.07-0.09$ wide at base, approximately 3-6 filitriches $/ \mu \mathrm{m}^{2}$. Distal bothridial surface covered by slender coniform spinitriches, 0.72-0.91 long, $0.20-0.25$ wide at base, 5-9 spinitriches/ $\mu \mathrm{m}^{2}$, interspersed with acicular filitriches, $0.21-0.25$ long, $0.07-0.10$ wide at base, approximately 7-12 filitriches/ $\mu \mathrm{m}^{2}$ (Figs. 16, 17). Bothridial stalks 100-330 (195 \pm 53 , $\mathrm{n}=12, n=37$ ) long, attached to middle of proximal bothridial surface; covered by acicular filitriches, 0.44-0.61 long, $0.14-0.17$ wide at base, $34-39$ filitriches $/ \mu \mathrm{m}^{2}$ (Fig. 18). Cephalic peduncle 112-350 (211 $\pm 80, \mathrm{n}=11)$ long, 150-230 $(176 \pm 26, \mathrm{n}=11)$ wide, covered by acicular filitriches, 0.29-0.34 long, 0.12-0.16 wide at base, approximately 20-27 filitriches $/ \mu \mathrm{m}^{2}$ (Fig. 19).

Immature proglottids wider than long (Fig. 5). Mature proglottids (excluding terminal proglottid) wider than long becoming longer than wide, 122-665 (249 \pm 123 , $\mathrm{n}=16, n=83)$ long, 225-627 (361 $\pm 95, \mathrm{n}=16, n=83)$ wide (velum not included in proglottid length); length to width ratio $0.3-2.1(0.7 \pm 0.4, \mathrm{n}=16, n=83)$ : 1 ; velum $10-142(74 \pm 38, \mathrm{n}=16, n=82)$ long, covering $2-45 \%$ ( $26 \pm 13, \mathrm{n}=16, n=66)$ of adjacent proglottid. Marginal genital pores alternate irregularly, 44-69\% $(59 \pm 6, \mathrm{n}=8$, $n=54$ ) of proglottid length from posterior margin of proglottid.

Majority of terminal mature proglottids longer than wide, $380-805 \quad(554 \pm 142, \mathrm{n}=13) \quad$ long, 215-392 $(297 \pm 56, \mathrm{n}=13)$ wide; length to width ratio $0.7-2.8$ $(1.8 \pm 0.5, \mathrm{n}=13): 1$; genital pores $60-81 \%(71 \pm 6$, $\mathrm{n}=10$ ) of proglottid length from posterior margin of proglottid (Figs. 21, 26). Terminal proglottid covered by acicular filitriches $0.14-0.20$ long, $0.09-0.12$ wide at base, $54-66$ filitriches $/ \mu \mathrm{m}^{2}$ (Fig. 20).

Testes oval, $4-7(5 \pm 1, \mathrm{n}=16, n=82)$ per proglottid, 22-100 (62 $\pm 14, \mathrm{n}=16, n=149)$ long, $18-67$ (41 \pm 11 , $\mathrm{n}=16, n=149$ ) wide; distributed in 2 irregular columns from anterior margin of proglottid to anterior margin of cirrus sac, reaching anterior margin of aporal ovarian lobe in some proglottids (Fig. 26), 1 row deep in cross-section (Fig. 27). Cirrus sac pyriform, straight to slightly curved posteriorly, $62-200(138 \pm 37, \mathrm{n}=16, n=88)$ long, 40-140 (93 $\pm 25, \mathrm{n}=16, n=88)$ wide, containing cirrus covered by spinitriches 2 long (Fig. 26). Vas deferens extending anteriorly from level of Mehlis' gland to level of posteriormost testes on dorsal side of proglottid, entering cirrus sac anteriorly, $15-37(26 \pm 6, \mathrm{n}=14, n=44)$ maximum width (Figs. 26, 29).

Vagina thick-walled, opening anterior to cirrus in genital atrium, running along anterior margin of cirrus sac, descending posteriorly to ootype region. Ovary lobulated, $\mathrm{H}$-shaped in dorsoventral view (Fig. 26), tetra-lobed in cross-section at level of ovarian isthmus (Fig. 29), maximum width $150-370(230 \pm 64, \mathrm{n}=15, n=44)$, poral lobe 60-285 (134 $\pm 53, \mathrm{n}=15, n=44)$ long, aporal lobe slightly longer than poral lobe $65-330(151 \pm 61, \mathrm{n}=15$, $n=44)$ long. Vitelline follicles oval, 10-45 (25 \pm 7 , $\mathrm{n}=16, n=122)$ long, $8-37 \quad(18 \pm 7, \mathrm{n}=16, n=122)$ wide; distributed in columns, 1-4 follicles deep (1-2 dorsal, 1-2 ventral) at each side of proglottid, interrupted dorsally on poral side at level of terminal genitalia, and 

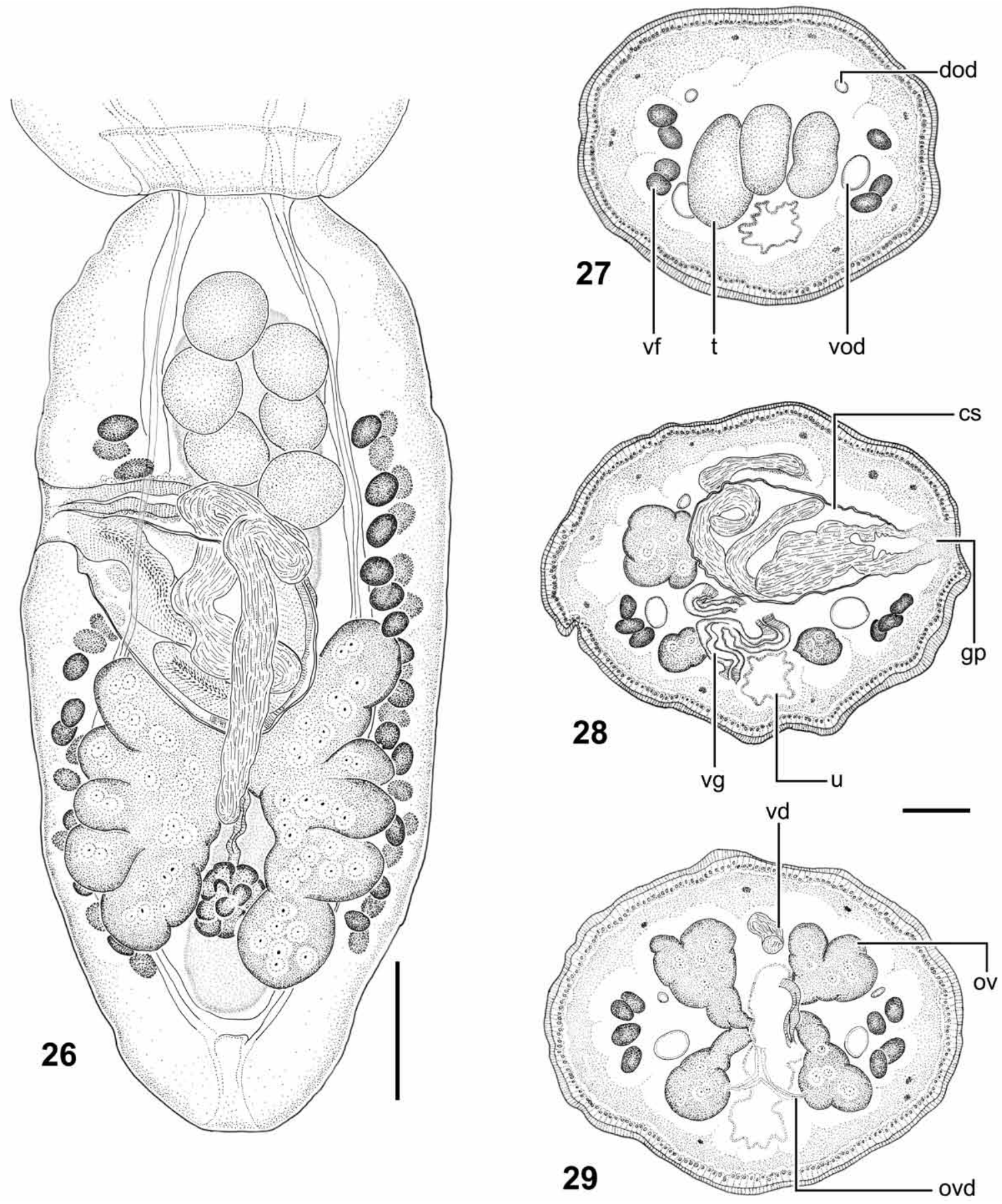

Figs. 26-29. Rhinebothrium mistyae sp. n. Fig. 26. Dorsal view of terminal proglottid (paratype MACN-Pa 516). Figs. 27-29. Crosssections of mature proglottid (paratype MACN-Pa 516). Fig. 27. At level of testes. Fig. 28. At level of cirrus sac. Fig. 29. At level of ovarian isthmus. Abbreviations: cs - cirrus sac; dod - dorsal osmoregulatory duct; gp - genital pore; ov - ovary; ovd - oviduct; $\mathrm{t}$ - testis; $\mathrm{u}$ - uterus; vd - vas deferens; vf - vitteline follicle; vg - vagina; vod - ventral osmoregulatory duct. Scale bars: Fig. $26=100 \mu \mathrm{m}$; Figs. $27-29=50 \mu \mathrm{m}$.

not interrupted by the ovary (Figs. 26-29). Mehlis' gland $27-75(49 \pm 13, \mathrm{n}=10, n=22)$ in diameter, posterior to ovarian isthmus. Uterus saccate, visible in mature proglottids, extending to near posterior margin of proglottid and anteriorly to near anterior margin of proglottid.
Ty pe host: Potamotrygon motoro (Müller et Henle), South American freshwater stingray (Rajiformes, Potamotrygonidae).

Type locality: Colastiné River, Paraná River basin, Santa Fé, Argentina $\left(31^{\circ} 40^{\prime} \mathrm{S}, 60^{\circ} 46^{\prime} \mathrm{W}\right)$.

Other 1 ocalities: Coronda River $\left(31^{\circ} 50^{\prime} \mathrm{S}, 60^{\circ} 49^{\prime} \mathrm{W}\right)$; 
Setúbal Lagoon $\left(31^{\circ} 32^{\prime} \mathrm{S}, 60^{\circ} 36^{\prime} \mathrm{W}\right)$, and Alto Verde $\left(31^{\circ} 39^{\prime} \mathrm{S}, 60^{\circ} 40^{\prime} \mathrm{W}\right)$, Paraná River basin, Santa Fé, Argentina. Site of infection: Spiral intestine.

Prevalence and intensity of infection: Twelve out of 37 hosts examined (34\%), 1-6 (2.6) worms per host.

Specimens deposited: Holotype and 3 paratypes, MACN-Pa No. 516/1-4 (whole worms); 2 paratypes, IPCAS No. C-606. Additional specimens (whole mounts, histological sections, and specimens prepared for SEM) retained in the personal collection of Verónica Ivanov.

Etymology: This species is named after "Misty", the fox terrier dog of the first author.

Remarks. Rhinebothrium mistyae can be readily distinguished from 34 of the 41 valid species of the genus in its possession of a greater number of proglottids per worm (353-974 vs. less than 310). Rhinebothrium mistyae differs from the remaining seven valid Rhinebothrium species ( $R$. ceylonicum, $R$. euzeti, $R$. hui Tseng, 1933, $R$. wal$g a, R$. copianullum, $R$. paratrygoni, and $R$. corbatai) as follows: it has almost twice the number of loculi per bothridium than $R$. ceylonicum, $R$. hui, and $R$. walga (75-79 vs. approximately 40-42), and it is longer than $R$. euzeti (20.0-59.9 mm long vs. $5 \mathrm{~mm}$ long). Rhinebothrium mistyae has fewer loculi per bothridium than $R$. copianullum (75-79 vs. 79-87), a smaller cirrus sac (62-202 vs. 280-380 long), and lacks the vaginal sphincter described by Reyda (2008). Both species also differ in the microthrix pattern, particularly on proximal and distal surfaces of bothridia. Whereas in R. mistyae spinitriches and filitriches are uniformly distributed on the proximal and distal bothridial surfaces, spinitriches are lacking from the bothridial rims and at the level of transverse septa on proximal bothridial surfaces of $R$. copianullum (see Reyda 2008). Rhinebothrium mistyae most closely resembles $R$. paranaense in worm length, number of proglottids per worm, and scolex size; however, $R$. mistyae has more loculi per bothridium than $R$. paranaense (75-79 vs. 65-69), larger spinitriches on the proximal bothridial surface (1.49-1.69 vs. 1.06-1.34 long), and those spinitriches are coniform instead of gladiate as in $R$. paranaense. In addition, the vas deferens runs posteriorly from the anterior margin of the cirrus sac to the level of Mehlis' gland in R. mistyae (Figs. 26, 29), but is only seen anterior to the cirrus sac in R. paranaense (fig. 6 in Menoret and Ivanov 2009).

Given the somewhat superficial nature of the original description and illustrations of $R$. paratrygoni (see Rego and Dias 1976) and the poor condition of type specimens (see Reyda 2008), the morphology of this species remains to be confirmed. Based on the scarce information currently available, $R$. mistyae has a wider strobila $(380-805$ vs. 300) and a shorter cephalic peduncle (112-350 vs. 750 ) than $R$. paratrygoni. Finally, $R$. mistyae is different from $R$. corbatai described above from the same host, in being conspicuously longer $(20.0-59.9 \mathrm{~mm}$ vs. $3.3-7.5 \mathrm{~mm}$ ), having a greater number of proglottids per worm (353-974 vs. 96-190), and a greater number of mature proglottids ( $10-49$ vs. $2-4$ ).

\section{DISCUSSION}

Freshwater stingrays of the family Potamotrygonidae occur in most South American rivers basins that drain into the Atlantic Ocean and Caribbean Sea, being absent in the São Francisco River, rivers from the Atlantic rainforest of Brazil, and rivers south of the Río de La Plata in Argentina (Carvalho et al. 2003). Potamotrygonids are currently represented by 20 species in three genera: the monotypic Paratrygon Duméril and Plesiotrygon Rosa, Castello et Thorson as well as 18 species of Potamotrygon Garman (see Froese and Pauly 2011).

Only five species of Rhinebothrium have been reported from a total of nine species of potamotrygonids: R. copianullum from Paratrygon aiereba (Müller et Henle) in Peru, $R$. paranaense from Potamotrygon falkneri Castex et Maciel, $R$. mistyae and $R$. corbatai from P. motoro in Argentina, and $R$. paratrygoni reported from a total of nine species of freshwater stingrays from a diversity of rivers and basins (e.g. Orinoco, Paraguay, Paraná, Tocantins, Xingú, Negro, Lower Amazonas) (Brooks and Amato 1992, Marques 2000, Reyda 2008, Menoret and Ivanov 2009, present study). However, the morphology of $R$. paratrygoni is poorly known, therefore identifications and records of $R$. paratrygoni should be reconsidered. The fact that this species was originally described from an unknown host and that the type specimens are in poor condition (see Reyda 2008, Menoret and Ivanov 2009), makes a redescription and clarification of its taxonomic status difficult. Unfortunately, many of the voucher specimens on which records of $R$. paratrygoni from various hosts and localities were based, are not deposited in collections and so are not available for re-examination, comparison with the new species recently described, and perhaps re-identification. As suggested by Reyda (2008) some of the specimens previously identified as belonging to this species could represent new taxonomic entities. In fact, $P$. motoro has been reported as a host for $R$. paratrygoni in Corumba (Paraguay River) (Brooks and Amato 1992). In the present study, two species of Rhinebothrium (i.e. R. corbatai and R. mistyae) collected from P. motoro in the same hydrographic basin are shown to be distinct from $R$. paratrygoni. Also, Reyda (2008) reported the presence of an undescribed species of Rhinebothrium, different from $R$. paratrygoni reported from P. motoro from the Madre de Dios River in southeastern Peru. Brooks and Amato (1992) reported in a host-parasite checklist the presence of $R$. paratrygoni in $P$. motoro but did not give information on the morphology of the collected specimens. Those specimens might represent the species herein described, or the species Reyda (2008) refers to as Rhinebothrium sp. 1, rather than R. paratrygoni. Fur- 
thermore, records of parasites from species such as $P$. motoro should be considered with caution according to their geographic distribution, since this host clearly represents a species complex as mentioned by Rosa et al. (2008).

It seems multiple species of Rhinebothrium parasitizing the same host are not rare in freshwater environments. Healy (2006) described three species from a single host species in the Kinabatangan River (Malaysia), Reyda (2008) described $R$. copianullum and mentioned the presence of a second undescribed species in $P$. aiereba in Peru, and two species were found co-occurring in $P$. motoro in Argentina in the present study.

Considering that records of Rhinebothrium are unequivocal from only 3 of the 20 currently described species of potamotrygonids, and the pattern of high host specificity exhibited by most species in the genus (Healy 2006), along with the fact that multispecies infections seem to be frequent in this genus, it is expected that more than 20 species of Rhinebothrium are yet to be discovered in the freshwater stingrays of the Neotropical region.

Acknowledgments. Thanks are due to the fishermen Piti, Calilo, Martín, and Tuna, who met the challenge of collecting freshwater stingrays for this study, to Eduardo Lordi for the assistance in the field and for providing lodging, and to the authorities of the INALI (Instituto Nacional de Limnología - CONICET) for the use of their facilities. We would like to thank Janine Caira from the University of Connecticut, USA, for facilitating our work through the Global Cestode Database. This work has been funded by grant PICT 2006 No. 825 from Agencia Nacional de Promoción Científica y Tecnológica (ANPCyT, Argentina), grant UBACyT (2008-2010) X453, UBACyT (2010-2012) 20020090200511 from Universidad de Buenos Aires (Argentina), CONICET-PIP (2011-2013) 11420100100237 to VAI, and NSF PBI Nos. 0818696 and 0818823 (USA).

\section{REFERENCES}

Brooks D.R., Amato J.F.R. 1992: Cestode parasites in Potamotrygon motoro (Natterer) (Chondrichthyes: Potamotrygonidae) from Southwestern Brazil, including Rhinebothroides mclennanae n. sp. (Tetraphyllidea: Phyllobothriidae), and the revised host-parasite checklist for helminths inhabiting Neotropical freshwater stingrays. J. Parasitol. 48: 43-64.

Brooks D.R., Thorson T.B., Mayes M.A. 1981: Freshwater stingrays (Potamotrygonidae) and their helminth parasites: testing hypotheses of evolution and coevolution. In: V.A. Funk and D.R. Brooks (Eds.), Advances in Cladistics: Proceedings of the Willi Henning Society. New York, USA, pp. 147-175.

Carvalho M.R., Lovejoy N.R., Sosa R.S. 2003: Family Potamotrygonidae (River stingrays). In: R.E. Reis, O. Kullander and C.J. Ferraris (Eds.), Check List of the Freshwater Fishes of South and Central America. Porto Alegre, Brazil, pp. 22-28.

Chervy L. 2009: Unified terminology for cestode microtriches: a proposal from the International Workshops on Cestode Systematics in 2002-2008. Folia Parasitol. 56: 199-230.

Froese R., Pauly D. (Eds.) 2011: FishBase. World Wide Web electronic publication. www.fishbase.org, version (2/2011).

Healy C.J. 2006: Three new species of Rhinebothrium (Cestoda: Tetraphyllidea) from the freshwater whipray, Himantura chaophraya, in Malaysian Borneo. J. Parasitol. 92: 364-374.

Received 22 October 2010
Healy C.J., Caira J.N., Jensen K., Webster L., Littlewood D.T.J. 2009: Proposal for a new tapeworm order, Rhinebothriidea. Int. J. Parasitol. 39: 497-511.

Marques F.P.L. 2000: Evolution of Neotropical freshwater stingrays and their parasites: taking into account space and time. $\mathrm{PhD}$ thesis. University of Toronto, Canada, $325 \mathrm{pp}$.

Menoret A., Ivanov V.A. 2009: A new species of tetraphyllidean (Cestoda) from the largespot river stingray, Potamotrygon falkneri (Potamotrygonidae: Chondrichthyes), from the Paraná Basin. J. Parasitol. 95: 994-999.

Rego A.A., Dias A.P.L. 1976: Estudos de cestóides de peixes do Brasil. $3^{\mathrm{a}}$ nota: Cestóides de raias fluviais Paratrygonidae. R. Bras. Biol. 36: 941- 956.

REYDA F.B. 2008: Intestinal helminths of freshwater stingrays in southeastern Peru, and a new genus and two new species of cestode. J. Parasitol. 94: 684-699.

Rosa R.S., Carvalho M.R., Wanderley C.A. 2008: Potamotrygon boesemani (Chondrichthyes: Myliobatiformes: Potamotrygonidae), a new species of Neotropical freshwater stingray from Surinam. Neotrop. Ichthyol. 6: 1-8.

Accepted 1 March 2011 